Al-Bayyinah: Journal of Islamic Law- ISSN: 1979-7486 (p); $\underline{2580-5088}$ (e) Volume VII Number 2, pp. 59 - 80

\title{
JHAD DAN TERORISME DALAM PANDANGAN HUKUM ISLAM (Sebuah Analitis Kritis Terhadap Skenario Politik Global)
}

\section{Sudianto}

(Dosen Fakultas Syariah dan Hukum UIN Medan)

\section{Abstract}

Jihad is to mobilize all abilities to achieve goals with no surrender and despair, so in this case jihad is not only against the enemy but if there is a leader of the fight against unemployment, poverty, eradicate immoral pursuit of pleasure of Allah and for the welfare of its people then this could also referred to as jihad. While terrorism is any act of political violence that has no moral and legal justification, whether it is an act of violent revolutionary group or government / state. Terrorism has two categories, first is the horrific terrorism, that terrorism is truly evil because it destroys private property and state and kill people without reason that rational and unconventional manner. Second, heroic terrorism, namely acts of terrorism to fight for life, such as suicide bombings carried out Palestinian youth. Actions taken as lacking any other choice. So the first category is condemned by Islam because it has been killing innocent people, even the perpetrators can be subject to capital punishment. While the second category is a form of holy struggle that when the fighters are dead they are called martyrs for defending the truth and want to obtain their rights which are usurped by the Zionist state.

Kata Kunci: Jihad, terorisme, hukum Islam dan politik global 


\section{A. Latar Belakang Masalah}

Al-Quran menganjurkan kaum Muslimin untuk berperang (jihad) melawan-musuh-musuh Islam dan Muslimin yang tidak mau berdamai. Namun perlu dipahami bahwa alQuran berbicara dalam hal ini tentang orang-orang yang tertindas, yang terusir dari tanah air mereka. Al-Quran menganjurkan kepada mereka untuk mengorganisasi diri mereka untuk membela diri dari penindasan dan untuk mencapai kehormatan/harkat diri dan agama (izzul Islam dan Muslimin). Berbagai masalah yang muncul mengenai makna dan hakikat jihad itu sendiri apakah mengutamakan jiwa atau ada alternatif lain yang lebih fleksibel untuk menghadapi musuh-musuh Islam tersebut, kemudian aksi pembelaan ini sering dituding oleh Amerika dan Sekutunya sebagai aksi teroris. Sehingga mereka ingin membasminya dan mengejar kaum Muslimin dimanapun mereka berada apalagi pasca tragedi 11 September 2001.

Peristiwa 11 September 2001 yang menelan korban lebih dari enam ribu jiwa yang tidak berdosa termasuk ratusan kaum Muslimin itu telah menimbulkan amarah yang luar biasa dari masyarakat dan negara yang paling dominan korban jiwanya, terutama AS, dan negara-negara Eropa. Para pelaku peristiwa tersebut kemudian dikenal dengan panggilan para teroris. Istilah ini dalam kehidupan dan sejarah AS bukanlah istilah yang baru dan aneh. Walaupun istilah terorisme ini dikalangan publik AS dan juga Eropa tidak asing, namun dengan munculnya nama-nama teroris yang kemudian diketahui bernama Arab-Islam, maka semakin memperkuat prejudis bahwa istilah teroris ini mempunyai konotasi yang berakibat sangat negatif bagi agama dan umat Islam. Islam dan Muslim dianggap identik dengan teroris dan terorisme. Bahkan beberapa orang pemimpin gereja ada yang terang-terangan menuduh Nabi Muhammad saw. sebagai teroris Maka dalam makalah yang sederhana ini penulis mengemukakan sedikit pemahaman tentang jihad dan terorisme.

Berbagai stigma dan pandangan terhadap Islam, sebagai agama teror dan melegalkan kekerasan dan umat Islam sebagai teroris. Padahal Islam adalah agama rahmatan 
lil alamin seakan kehilangan makna. Tulisan ini hendak mengkaji mengenai makna jihad dan terorisme dalam pandangan hukum Islam. Cap terorisme yang dikumandangkan oleh media Barat, sejarah terorisme dunia dan Indonesia serta skenario politik global.

\section{B. Jihad dalam Pelbagai Perspektif \\ 1. Pengertian Jihad}

Secara etimologi kata jihad berasal dari bahasa Arab yang artinya adalah kesungguhan, kekuatan, dan kelapangan. Namun secara terminologi terdapat pola pandang yang berbeda dikalangan ulama diantaranya:

1. Al-Maraghi mendefinisikan jihad adalah mengerahkan segenap kekuatan dan kemampuan untuk melawan musuh. ${ }^{1}$

2. Sady Abu Jaib menguraikan bahwa jihad adalah mengerahkan segala kemampuan untuk menghadapi musuh atau usaha yang sungguh-sungguh dalam memerangi orang kafir. $^{2}$

3. M.Quraish Shihab mengatakan bahwa jihad adalah mencurahkan seluruh kemampuan atau menanggung pengorbanan. ${ }^{3}$

Dari beberapa pengertian jihad yang dikemukakan ulama diatas, kelihatannya sebahagian ulama memahami makna jihad identik dengan berjuang dijalan Allah dan harus memerangi musuh-musuh Allah sehingga kedamaian dan ketenteraman bisa terwujud di bumi Allah ini. Namun demikian jihad adalah mengerahkan segala kemampuan untuk mencapai tujuan yang tak kenal menyerah dan putus asa, jadi dalam hal ini jihad bukan hanya melawan musuh tetapi bila ada seorang pemimpin yang memerangi pengangguran, kemiskinan, memberantas maksiat demi mencapai ridha Allah dan demi kesejahteraan rakyatnya maka hal ini bisa juga disebut dengan jihad.

${ }^{1}$ Ahmad Musthafa al-Maraghi, Tafsir al-Maraghi, Cairo: Dar alFikr, t.th. Jilid I., h. 137.

2 Sady Abu Jaib, al-Qamus al-Fiqhi Lughatan wa Istilahan, Damaskus: Dar al-Fikr, 1998., h. 71.

${ }^{3}$ M.Quraish Shihab, Tafsir al-Misbah, Vol. I, Jakarta: Lentera Hati, 2002., h. 426. 


\section{Jihad dalam Interprestasi Para Ulama}

Sayyid Qutub salah satu tokoh terkemuka asal Mesir mengemukakan bahwa harus angkat senjata melawan orang kafir dan tidak ada rasa belas kasihan terhadap mereka sedikitpun demi menegakkan hukum Allah di muka bumi. ${ }^{4}$ Pendapat seperti ini terasa amat logis karena memang Mesir yang sebelumnya dijajah oleh Inggris dan Prancis tentunya wajar kalau ia berpendapat demikian, walaupun Mesir telah memperoleh kemerdekaan namun pengaruh imperalisme kaum penjajah tentunya masih melekat secara kuat. Kemudian juga memang Sayyid Qutub sebagai tokoh gerakan Ikhwanul Muslimin yang selalu ditekan bahkan dihabisi oleh penguasa, jadi ia berpendapat demikian dinilai sangat wajar demi menghadapi sebuah kezaliman. Juga karena Mesir secara geografis berbatasan dengan Israel yang mana situasinya waktu itu masih dalam suasana perang.

Pendapat lain yang lebih moderat seperti al-Jashas mengemukakan bahwa jihad dengan ilmu adalah lebih utama. Demikian juga halnya dengan Mushtafa al-Maraghi yang mana beliau membagi jihad kepada tiga macam yaitu:

$>$ Jihad melawan musuh yang tampak,

$>$ Jihad melawan Syaitan

$>$ Jihad melawan hawa nafsu. ${ }^{5}$

Begitu juga dengan ulama kontemporer seperti Hamka, Wahbah al-Zuhaily mereka mengemukakan bahwa jihad tidak mesti mengangkat senjata akan tetapi bisa juga menahan perasaan dan juga menuntut ilmu dan menyebarkan dakwah Islamiyah. Karena menurut Hamka makna jihad itu sendiri adalah berjuang bersungguh-sungguh atau bekerja keras, tidak peduli payah. ${ }^{6}$

Beraneka ragam jihad dari segi lawan dan buahnya, ada jihad melawan orang-orang kafir, munafik, setan, hawa nafsu, dan lain-lain, maka buahnya pun berbeda-beda. Jihad ilmuwan

${ }^{4}$ Sayid Qutub, Fi Zhilal al-Quran, Beirut: Dar al-Arabiyah, t.th., Jilid. IV, h. 197.

${ }^{5}$ Al-Maraghi, Tafsir al-Maraghi.. Jilid IV, h. 124.

${ }^{6}$ Wahbah al-Zuhaily, al-Fiqh al-Islam wa Adillatuhu, Beirut: Dar al-Fikr, 1997, Jilid VI., h. 197. 
dengan pemanfaatan ilmunya, karyawan dengan karyanya yang baik, guru dengan pendidikan yang sempurna, pemimpin dengan keadilannya, pengusaha dengan kejujurannya, pemangkul senjata dengan kemerdekaan dan penaklukan musuh yang zalim. Semua jihad, apapun bentuknya dan siapa pun lawannya, harus karena Allah dan tidak boleh berhenti sebelum berhasil atau kehabisan modal.

\section{Terorisme: Antara Harga Diri dan Fitnah Media Barat 1. Pengertian Teroris}

Teroris secara bahasa adalah pengacau, orang yang melakukan teror. Terorisme adalah hal pengacau dalam masyarakat untuk mencapai tujuan (dalam bidang politik). Defenisi umum terorisme yang populer adalah "setiap tindakan kekerasan politik yang tidak memiliki justifikasi moral dan hukum, apakah tindakan kekerasan itu dilakukan suatu kelompok revolusioner atau pemerintah/negara. Dalam hal ini, respon publik terhadap kekerasan ketakutan sebagai akibat yang ditimbulkan oleh terorisme merupakan bagian dari makna istilah tersebut.

Terorisme seakan-akan indentik dengan Islam, setiap orang menyebut kata teroris yang ada di benak sebagian besar kita adalah sosok Usamah Bin Laden atau para teroris Muslim lainnya. Pada keyataannya banyak teroris yang bukan Islam seperti : Amum Shinrikyo di Jepang, Macan Tamil di Srilangka, Kahane Chai di Israil, Kelompok Nopember 17 di Yunani, Tupak Amaru di Peru, Farc di Kamboja, dan kelompok America Militant Extremists di Amerika Serikat sendiri. Menurut John Naisbith, bahwa Amerika adalah sarang terorisme, fundamentalisme, dan radikalisme.

Hal ini menunjukkan bahwa terorisme ternyata justru lebih banyak dilakukan orang di luar Islam. Terorisme hanyalah fitnah yang dilontarkan oleh orang-orang Barat melalui media massa dan media elektronik kian hari mempengaruhi opini publik (public opini). Yang lebih menyedihkan lagi beberapa Negara Islam ikut mendukung program Barat tersebut terutama Amerika, misalnya Pakistan. Pakistan beberapa waktu lalu membom sebuah madrasah di wilayah perbatasan Pakistan dan Afghanistan. Sedikitnya 60 orang tewas, kebanyakan berusia 
remaja, karena mereka umumnya pelajar. Mereka dibunuh secara sadis oleh bangsa mereka sendiri dengan tuduhan madrasah tersebut tempat pelatihan jaringan terorisme alQaedah. Banyak sekali warga sipil yang tidak berdosa yang menjadi korban, mereka disiksa, disakiti, dibunuh tanpa melalalui proses pengadilan.

Pada konteks yang lain tindakan Israel yang menyerang tanpa perikemanusiaan warga Palestina dan Libanon dan negara-negara Arab lainnya. Kenapa tidak disebut terorisme, lain halnya dengan di Irak ribuan orang sipil mati atau cacat tidak disebut teroris melainkan disebut dengan kata "aksi pembalasan", "response", atau "pencegahan". Berarti pakar sosial politik Barat sendiri belum ada kata sepakat dengan definisi yang sebenarnya dengan kata lain definisi teroris berdasarkan misi politiknya. J. Bowyer Bell mengatakan bahwa teroris adalah senjata kaum yang lemah. Dengan demikian masyarakat Barat yang selama ini terprovokasi dengan media yang anti Islam dan mengaitkan orang Islam dengan teroris, perlu meninjau kembali asumsi negatif tersebut yang sudah tertanam semenjak dini.

\section{Sejarah Teroris di Dunia dan di Indonesia}

Perkembangan global yang berawal dari Perang Dingin atau antara Blok Timur yang direpresenatasikan oleh Uni Sovyet dan Blok Barat direpresentasikan oleh Amerika Serikat dan sekutunya, telah menyisakan kawasan yang kosong dari kedua pengaruh kekuatan dunia. Kawasan itu tiada lain adalah kawasan yang kemudian kita kenal Timur Tengah, seusai Perang Dingin yang dimenangkan oleh Blok Barat dengan pionernya AS, maka iapun segera telah menanamkan "anak emasnya" Israel ditengah-tengah kawasan Timur Tengah dan sekaligus melakukan tindakan ketidak-adilan dan kesewenang-wenangan atas bangsa Palestina. Inilah yang kemudian yang menjadi biang keladi perlawanan orang tertindas atas suatu institusi negara dan pemerintahan yang amat kuat dan tidak adil. Perlawanan secara diam-diam dan tiba-tiba itu kemudian dijuluki dengan sebutan terorisme. 
Dapat dikatakan bahwa inilah awal era terorisme sebagaimana yang dikenal sekarang ini, pemaksaan kehendak suatu kelompok atau suatu golongan dengan tindakan teror, pembunuhan, pembantaian, pemerkosaan, penculikan dan penyendaraan. Pembuatan pernyataan "agar dunia tahu siapa kami" dengan tindakan-tindakan biadab dan tidak manusiawi yang dilakukan dengan tiba-tiba, tak terduga dan tak disangkasangka, imbasnya terhadap orang yang tak bersalah.

Sekutu Amerika di kawasan Asia Pasifik seperti, Singapura maupun Australia, mengeluarkan tuduhan bahwa Indonesia merupakan sarang jaringan teroris, dengan kata lain di Indonesia tempat bersembunyinya tokoh-tokoh teroris Asia Tenggara. Amerika Serikat menilai Indonesia merupakan mata rantai paling lemah di kawasan Asia Tenggara Pasifik dalam kerja sama global memerangi terorisme internasional. Alasannya, karena kepulauan Indonesia yang terdiri dari belasan ribu pulau yang tersebar, dan ada diantaranya yang terisolasi dari kehidupan dan kemudian lemah terhadap penegakkan hukum.

Dalam peran yang lebih kecil adalah PM Malaysia waktu itu Mahatir Muhammad, yang mengail untung dengan program pembasmian teroris ini melalui penangkapan sejumlah oposisi dalam negeri. Sehingga proyek terorisme yang memiliki kaitan erat dengan gerakangerakan Islam ini dimaknai sebagai cara menghabisi kekuatan Islam di kawasan Asia Tenggara. Kenyataan ini mudah dipahami mengingat perburuan serta penangkapan sejumlah aktivis yang dikenai tuduhan sebagai teroris berjalan tidak transparan, pembuktian yang lemah sehingga tidak ada akuntabilitas publik. Peranan Amerika yang menonjol dalam memimpin program anti terorisme ini menyiratkan tuduhan akan keinginan untuk memimpin kembali dunia sesuai dengan seleranya. ${ }^{7}$

Nama yang menjadi tudingan Amerika Serikat dan sekutu-sekutunya di kawasan Asia adalah Ustadz Abu Bakar Ba'syir, pemimpin pondok pesantren Al-Mukmin, di Ngruki,

${ }^{7}$ Jurnal, BASIS, Jurnalisme Seribu Mata, No. 11-12, Tahun ke53, Yogyakarta, 2004. 
(Sukaharjo) Solo. Ia juga menjadi Majelis Mujahidin Indonesia (MMI) yang berpusat di Solo. CIA menuduhnya sebagai pemimpin Jamaah Islamiyah (JI) yang disebut-sebut sebagai sayap al-Qaedah di kawasan Asia tenggara. ${ }^{8}$ Begitu juga dengan di Indonesia yang baru-baru ini dikejutkan dengan kasus Pamulang, Aceh, banyak sekali orang yang ditangkap, diintrogasi, khususnya terhadap orang-orang yang berjenggot, memakai jubah karena diduga terlibat dengan berbagai aksi pengeboman yang terjadi di tanah air. Namun perlu juga untuk dicatat bahwa apa kasus-kasus tersebut murni menumpas para teroris atau hanya sekedar pengalihan isu politik dari keputusan DPR pada sidang paripurna yang menyetujui opsi $\mathrm{C}$ yang dinilai ada penyimpangan pada kasus Bank Century.

\section{Tragedi 11 September: Skenario Politik Global Amerika}

Setelah terjadinya peristiwa 11 September 2001 di New York dan Washington, mulailah timbul persoalan baru dalam dunia modern, yaitu terorisme. Peristiwa tersebut memberi suasana komunikasi yang baru. Tak pernah sebelumnya orang "luar" memperoleh sedemikian banyak realitas seperti yang ditimbulkan oleh peristiwa 11 september 2001. ${ }^{9}$

Amerika Serikat ketika itu mulai memfokuskan perhatian terhadap terorisme, di mana Amerika menganggap suatu masalah paling besar dalam dunia dewasa ini. Maka mulailah Amerika mencari dukungan terhadap anggota PBB dan ASEAN untuk memerangi terorisme. Kemudian membangun kualisi global anti teroris, dua pernyataan politik presiden Bush yang sentimental adalah kata-kata crusade (perang salib), dan tuduhan tanpa fakta terhadap Usamah bin Laden sebagai dalang dibalik terjadi serangan 11 September 2001 yang meruntuhkan menara kembar WTC dan Pentagon.

Jika nama pemimpin Al-Qaidah yaitu Usamah bin Laden mendadak popular di seluruh dunia pasca Tragedi 11 September 2001, maka Jamaah Islamiyah (JI) populer setelah tragedi 12 Oktober 2002 di Legian, Bali. Jauh sebelum tragedi

\footnotetext{
${ }^{8}$ Ibid.

${ }^{9}$ Ibid.
} 
bom Bali, teroris punya sejarah yang panjang di Indonesia, pada hal tahun 1957, Bung Karno diserang dengan granat di Perguruan Tinggi Cikini Jakarta. Bung Karno selamat, tetapi beberapa orang menjadi korban penyelamatan. Pada saat Idul Adha 1963 terulang lagi upaya pembunuhan terhadap Bung Karno kali ini yang menjadi korban adalah Zainal Arifin, yaitu tokoh NU yang menjadi ketua DPR.

Sesudah peristiwa 11 September, Amerika Serikat mulai memobilisasikan kampanye (perang menumpas teroris). Dengan mengancam negara yang tak mau mendukung misi mereka tersebut, dengan ancaman "If you vrent with us, you're against us". Amerika mendorong negara-negara lain untuk bergabung bersamanya tanpa kecuali, dan siapa saja dia ancaman ini sangat tegas, khususnya pemimpinan kelompokkelompok Islam yang radikal. Jika pada masa perang dingin Uni Sovyet dengan ideologi komunis ditempatkan sebagai musuh, maka kampanye anti terorisme menjadikan kelompok-kelompok radikal dan fundamentalis sebagai sasaran. ${ }^{10}$

Namun, yang lebih sering mendorong terjadinya aksiaksi terorisme adalah agama kadang-kadang melalui suatu perpaduan dengan faktor-faktor lain, tidak jarang sebagai motivasi utama. ${ }^{11}$ Walaupun selalu dinyatakan bahwa perang melawan terorisme itu bukan perang melawan kaum Muslimin, tetapi kenyataan serangan selalu ditujukan kepada mereka. Kebijakan dalam dan luar negerinya, seperti sepecial registration bagi pendatang yang berkunjung ke Amerika Serikat atau bukan warga negara dan imigran yang datang ke AS sebelum 30 September 2002 harus melakukan pendaftaran khusus kepada dinas imigrasi AS untuk disidik jari dan diwawancara.

Pelaksanaan kebijakan ini lebih mengutamakan dan mentargetkan warga negara yang berasal dari negeri-negeri

${ }^{10}$ Eko Prasetyo, Membela Agama Tuhan, Yogyakarta: Pustaka Pelajar, 2003, Cet. III, h. 115.

${ }^{11}$ Mark Juergensmeyer, Teror Atas Nama Tuhan, Jakarta: Nizam Press: 2002, h. 7. 
Islam. ${ }^{12}$ Kemudian yang pada awal tahun sembilan puluhan baik di Amerika maupun di Eropa hubungan Muslim dengan non Muslim begitu bagus dan saling toleransi antara mereka, namun pasca peristiwa WTC mereka langsung melakukan intimidasi terhadap kaum muslimin, melarang menggunakan simbol-simbol agama, bahkan yang bernama Islam seperti Muhammad, Ahmad dilakukan pemeriksaan yang ketat dalam birokrasi.

Sebelas September 2001 itu menimbulkan banyak masalah yang menimpa masyarakat Islam Amerika, bahkan secara khusus menimpa masyarakat Islam Amerika-Arab, atau imigran asal Timur Tengah, dan masyarakat Islam Amerika-Asia Selatan (seperti Indian dan pakistan). Mereka diperlakukan dengan penuh kecurigaan. Seminggu setelah peristiwa WTC, dilaporkan sebanyak 645 orang AmerikaArab dan Asia Selatan mendapat perlakuan yang tidak wajar dan menjadi obyek kejahatan.

Amerika Serikat dan sekutunya bersikap arogan dengan mendiskreditkan para aktivis Muslim dengan cara menghubung-hubungkan mereka dengan ekstrimisme dan terorisme. ${ }^{14}$ Padahal kalau mereka sadari hal ini mendorong lahirnya sikap psikologis kaum Muslimin yang paradoks, yakni anti Amerika hingga dalam bentuk-bentuk tindakan kekerasan, tindakan kekerasan itu dalam terminologi Amerika disebut terorisme. Termasuk didalamnya tindakan yang diambil oleh gerakan perjuangan pembebasan Palestina (PLO). Perjuangan yang suci bagi bangsa Palestina dimaknai terorisme oleh Amerika dan "anak kandungnya" sendiri, Israel. Inilah paradoks kebebasan dan perdamaian. Oleh karena itu, jika dilacak mana akibat dan mana penyebabnya, maka dapat pula dikatakan bahwa lahirnya terorisme, baik terorisme domestik maupun internasional,

${ }^{12}$ Juhaya S. Praja, Islam Globalisasi \& Kontra Terorisme, Bandung: Kaki Langit Membangun Peradaban dengan Ilmu, 2004, h. 49.

${ }^{13}$ Ibid., h. 58.

${ }^{14}$ Anders Uhlin, Oposisi Berserak, Bandung: Mizan,1998, Cet. II, h. 71-72. 
dalam istilah Amerika adalah sebagai akibat dari kebijakan luar negerinya sendiri. ${ }^{15}$

Hal senada juga diungkapkan oleh beberapa pengamat di AS kalau kejadian WTC tersebut adalah akibat ulah dari AS sendiri dan sekutunya. Lyindon La Rouche, kandidat presiden asal Partai Demokrat mengatakan bahwa Peristiwa 11 September itu adalah "ciptaan" Amerika Serikat Sendiri. ${ }^{16}$

Faktor lain yang menyebabkan terjadinya peristiwa tersebut karena kesombongan Amerika Serikat dan kegagalannya memaksa Israel untuk menyelesaikan sengketa dengan kaum Palestina. ${ }^{17}$ Amerika Serikat dituduh telah melakukan aksi terorisme karena kekejian yang dilakukannya selama Perang Vietnam, dan terdapat alasan untuk menganggap pemboman Hirosima dan Nagasaki sebagai aksi teroris. Tetapi istilah terorisme lebih sering dikait-kaitkan dengan aksi kekerasan oleh kelompokkelompok yang dicabut hak pilihnya, yang berusaha keras untuk mendapatkan bagian kekuasaan ataupun pengaruh. ${ }^{18}$

Oleh karena itu, ada yang memandang bahwa peristiwa WTC tersebut hanyalah skenario politik global Amerika. Dibalik dari skenario tersebut adalah keinginan untuk menguasai ladang minyak yang ada di Afghanistan dan Irak. Itulah sebabnya seusai tragedi WTC dengan sombongnya Amerika menyerang Afghanistan dan Irak. Penyerangan Afghanistan dengan dalih bahwa negara ini merupakan tempat persembunyian Usamah bin Laden, sedangkan penjajahan atas Irak dengan alasan negara tersebut sarang terorisme internasional yang membantu teroris untuk menyerang Amerika. Alasan-alasan tersebut sampai sekarang merupakan isapan jempol belaka alias tuduhan yang salah.

Hal tersebut menurut penulis ada benarnya karena sikap AS dan sekutunya terhadap negara Islam sangat

\footnotetext{
${ }^{15}$ Juhaya S. Praja, Islam Globalisasi..., h. 42.

${ }^{16}$ Juhaya S. Praja, Islam Globalisasi..., 54.

${ }^{17}$ Eko Prasetyo, Membela Agama..., h. 120.

${ }^{18}$ Mark Juergensmeyer, Teror Atas..., h. 6.
} 
bertolak belakang dengan piagam PBB dan tatanan internasional, apalagi dibawah kepemimpinan G.W. Bush Junior saat ini yang bersikap standar ganda terhadap Palestina, Irak, Iran dan Afghanistan. Maka menurut penulis sendiri untuk saat ini Amerika Serikatlah dan sekutusekutunya yang disebut teroris karena telah membunuh rakyat yang tidak berdosa seperti di Penjara Abu Gharib, Irak, Guantanamo, Cuba, dan lain-lain. Maka G. Bush, Ariel Sharon, Jhon Howard, Tony Blair layak diadili di Mahkamah Internasional sebagai penjahat perang.

Dengan demikian, jika Amerika menyatakan perang melawan terorisme, maka pada hakikatnya ia menyatakan perang melawan dirinya sendiri. Inilah bagian dari kehidupan peradaban yang diciptakan Amerika dan telah membuat ia sendiri terjerat oleh ciptaannya sendiri. Mengapa demikian? Jawabannya mungkin sekali berpusat pada filsafat kapitalisme dan sekularisme yang diagungkannya. ${ }^{19}$ Indikasi kearah tersebut telah mulai nampak, hal ini dapat dilihat dengan turunnya popularitas GW. Bush, disusul pula dengan kekalahan Partai Republik pada pemilihan anggota senat beberapa hari lalu (Nopember 2006). Perolehan kursi Partai Republik hanya 49, berbanding 51 Partai Demokrat. Kekalahan ini pula yang menyebabkan Menteri Pertahanan Donald Rumsfelth mengundurkan diri dari jabatannya beberapa saat setelah kekalahan Partai Republik. Padahal partai inilah yang mengantar Bush ke kursi kepresidenan. Banyak pakar politik mengakui bahwa kekalahan tersebut penyebabnya adalah kasus pencaplokan Irak. Nampaknya Irak akan menjadi Vietnam kedua bagi Amerika, dan inilah titik awal dari kejatuhan politik global Amerika.

Oleh karena itu, usaha untuk memerangi terorisme harus berangkat dari penyelesaian terhadap akar atau sumber masalah (core of the problems). Salah satu akar terpenting terorisme sekarang adalah ketidakadilan dan kepincangan dalam tata hubungan internasional, yang pada gilirannya menumbuhkan sikap standar ganda (double

${ }^{19}$ Juhaya S. Praja, Islam Globalisasi..., h. 42. 
standar) pada pihak pemegang dominasi dan hegemoni internasional yakni AS dan sekutu-sekutu Baratnya. Hanya dengan terciptanya tata internasional baru yang adil dan dengan demikian akan menciptakan perdamaian yang menghormati hak-hak setiap masyarakat dan bangsa, yang menjunjung tinggi pluralitas dan multikulturalisme, maka teror dan terorisme dapat dikurangi, jika tak bisa dihabisi sama sekali. ${ }^{20}$

Penulis sepakat dengan ungkapan diatas kalau AS ingin aman dari terorisme maka jangan bersikap arogan terhadap dunia ketiga khususnya umat Islam, jangan terlalu mendikte apalagi urusan dalam negeri Indonesia, maka dalam kunjungan GW. Bush yang kedua kali ke Indonesia pada tanggal 20 November 2006 mendatang yang menghabiskan dana 6 miliyar rupiah perlu disikapi hati-hati oleh pemerintah RI yang di bawah kepemimpinan Susilo Bambang Yudoyono dan Jusuf Kalla. Jangan sampai kita dijadikan orang asing di negeri kita sendiri, mereka hanya fatner bukan sekutu jadi jangan mau tunduk dengan kepentingan negara adikuasa tersebut.

Begitu juga dengan Barack Obama yang membatalkan kunjungannya ke Indonesia meskipun dengan alasan mempunyai agenda sendiri dalam negeri yaitu membahas Rancangan Undang-Undang kesehatan, yang membuat pemerintah Indonesia kecewa karena persiapan untuk menyambut orang nomor satu di negara adi daya tersebut sudah dianggap mapan.

Namun perlu juga untuk dicatat, meskipun Barack Obama pernah mengecap pendidikan di Indonesia, jangan sampai menimbulkan euforia yang berlebihan apalagi sampai menyembah karena tidak serta merta dia memenuhi keinginan Indonesia dalam berbagai hal. Apalagi pemimpin AS yang biasanya kebijakannya tidak jauh berbeda dengan pendahulunya, karena mereka juga punya kepentingan politik yang tidak sama dengan Indonesia. Meskipun peraih nobel perdamaian namun Obama dinilai gagal menundukkan

${ }^{20}$ Azyumardi Azra, Konflik Baru Antar Peradaban, Jakarta: Grafindo Persada, 2002, Cet. I, h. 84. 
PM Israel Benyamin Netanyahu untuk menghentikan kebiadabannya terhadap orang Palestina. Dengan demikan tidak perlu berharap banyak pada sosok Obama, meskipun mengaku kalau kebijakannya saat ini lebih dekat dengan umat Islam. Namun kenyataannya dia belum juga menarik pasukannya dari Irak, Afghanistan, yang mayoritas penduduknya muslim padahal ini merupakan kampanyenya yang lumayan populer sebelum menuju gedung putih.

\section{Terorisme dalam Pandangan Hukum Islam}

Terlepas dari penekanannya pada pengampunan dan pemberian maaf, al-Quran mengizinkan penggunaan kekerasan dalam kondisi-kondisi tertentu sesuai kebudayaan kesukuan Arab pra-Islam, yang telah melembagakan militer untuk membela keamanan kesukuan. Dalam memperkenalkan perintah yang mengabsahkan penggunaan terbatas kekerasan melalui sarana jihad, al-Quran merespons kondisi-kondisi politik dan religius-moral yang ada di Arab abad ke-7. keutamaan suatu suku bergantung pada sejauh mana mereka mampu melindungi semua klan mereka dan mampu membalas semua hinaan, luka, dan kematian melalui kekuatan militer mereka. Tindakan-tindakan agresif cukup lumrah dalam Arab pra-Islam. Berlawanan dengan latar belakang ini, penggunaan absah dan terbatas kekuatan fisik secara moral yang disetujui al-Quran merupakan suatu pengakuan terhadap realitas sifat manusia yang mendasari perubahan antara perdamaian dengan konflik dalam kondisi sosial politik yang keras dan kompleks. ${ }^{21}$

Berdasarkan fakta-fakta, maka terorisme dapat kategorisasi menjadi dua. Pertama, adalah horrific terorism, yakni terorisme yang benar-benar jahat karena menghancurkan kekayaan pribadi dan negara serta membunuh jiwa tanpa alasan yang rasional dan dengan cara yang tidak konvensional. Kedua, heroic terrorism, yakni tindakan terorisme untuk memperjuangkan hidup, seperti bom bunuh diri yang dilakukan pemuda Palestina. Tindakan

${ }^{21}$ Abdul Aziz Sachedina, Kesetaraan Kaum Beriman, Jakarta: Serambi Ilmu Semesta, 2001, Cet. I. h. 197. 
yang dilakukan karena tidak mempunyai pilihan lain. ${ }^{22}$ Maka kategori yang pertama sangat dikecam oleh Islam karena telah membunuh rakyat yang tidak berdosa, bahkan pelakunya dapat dikenakan hukuman mati sebagaimana disebutkan dalam al-Qur'an:

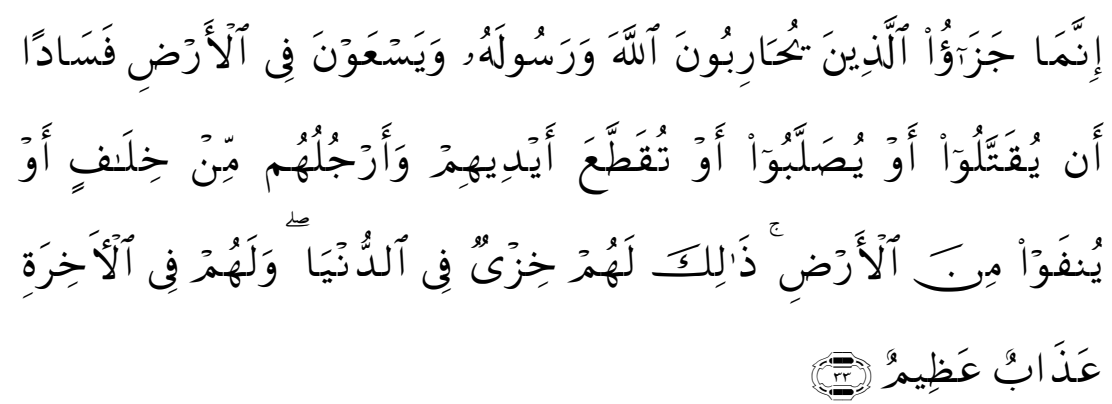

Artinya: Sesungguhnya pembalasan terhadap orangorang yang memerangi Allah dan rasul-Nya dan membuat kerusakan di muka bumi, hanyalah mereka dibunuh atau disalib, atau dipotong tangan dan kaki mereka dengan bertimbal balik atau dibuang dari negeri (tempat kediamannya). yang demikian itu (sebagai) suatu penghinaan untuk mereka didunia, dan di akhirat mereka beroleh siksaan yang besar (Q.S. Al-Maidah:33).

Berdasarkan ayat di atas bahwa orang yang melakukan kejahatan dan membunuh orang yang tidak berdosa maka layak diberikan hukuman yang maksimal, bahkan hukuman mati sekalipun karena mendapat legitimasi kuat dari Alquran. Sedangkan yang kategori yang kedua adalah merupakan bentuk perjuangan suci yang bila mati disebut dengan syuhada karena membela kebenaran dan ingin memperoleh hak-haknya yang dirampas oleh negara Zionis tersebut. Kategori ini mendapat pengakuan sebagai orang-orang yang berjuang di jalan Allah. Al-Qur'an menegaskan bahwa:

${ }^{22}$ Juhaya S. Praja, Islam Globalisasi..., h. 39. 


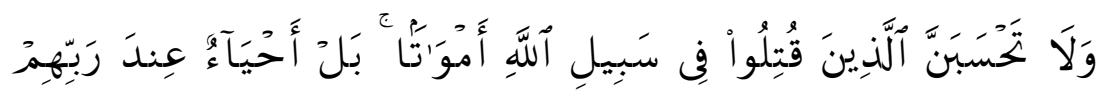

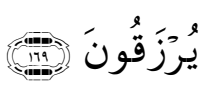

Artinya: Janganlah kamu mengira bahwa orang-orang yang gugur di jalan Allah itu mati; bahkan mereka itu hidup disisi Tuhannya dengan mendapat rezki (Q.S. Ali Imran: 169)

Kesimpulan dari ayat tersebut bahwa apabila ada yang tertindas, teraniaya dan terzalimi hak-haknya lantas dia mempertahankannnya, maka apabila dia mati maka disebut sebagai syuhada yang seakan-akan dia hidup selamanya. Jihad dalam pengertian perang sering diasosiasikan atau bahkan diidentikkan pihak Barat dengan "teror" dan "terorisme", sejauh mana jihad dapat menjadi "teror" dan "terorisme". Sebenarnya dapat dilihat justifikasi moral tindakan jihad itu, serta kesesuaian atau ketidaksesuaiannya dengan aspek-aspek lain ajaran Islam. ${ }^{23}$

Serangkaian kejadian aksi teror yang terjadi di Indonesia khususnya di dunia pada umumnya, yang dilakukan atas nama Islam. Pada kenyataannya seluruh agama tidak membenarkan terorisme atau tindakan kekerasan walaupun dalam kenyataan sejarah. Ajaran agama Islam sangat menentang, segala bentuk kekerasan, sebagai contoh dalam QS. al-An'am: 1 51;

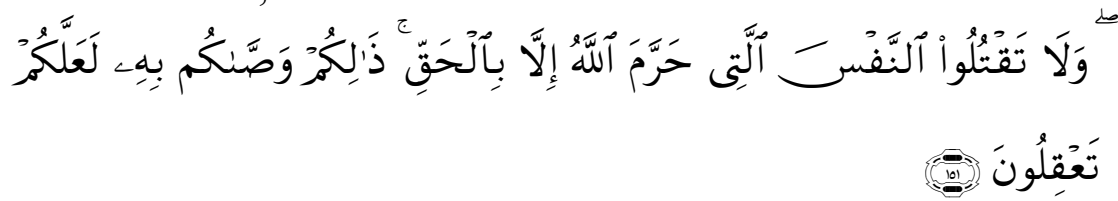

Artinya:"Janganlah membunuh jiwa yang Allah mengharamkan untuk membunuhnya, kecuali dengan alasan yang benar".

${ }^{23}$ Azyumardi Azra, Konflik Baru..., h. 8. 
Ayat lain adalah al-Maidah: 32:

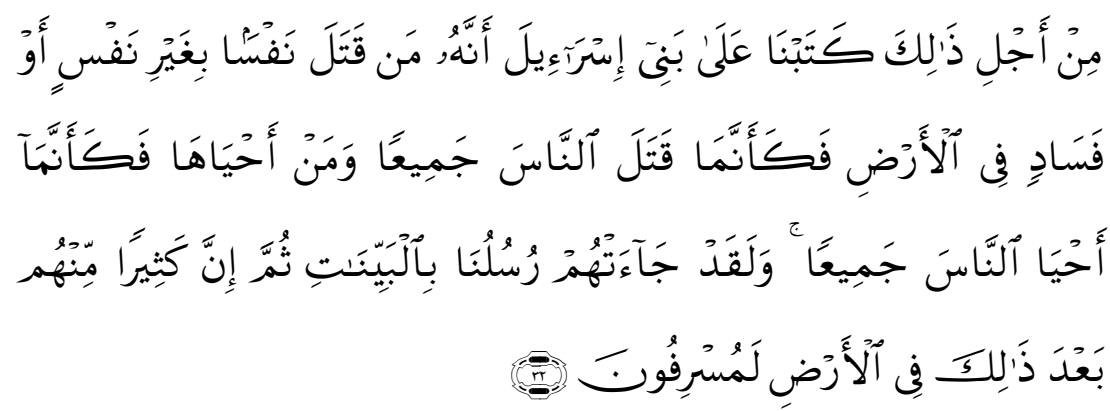

Artinya: Oleh karena itu, kami tetapkan (suatu hukum) bagi Bani Israil bahwa Barang siapa yang membunuh seorang manusia, bukan karena orang itu (membunuh) orang lain) atau bukan karena membuat kerusakan di muka bumi ini, maka seakan-akan dia telah membunuh manusia seluruhnya, dan barang siapa yang memelihara kehidupan seorang manusia, maka seolah-olah dia telah memelihara kehidupan manusia semuanya. Dan sesungguhnya telah datang kepada mereka rasul-rasul kami dengan (membawa) keterangan-keterangan yang jelas, kemudian banyak di antara mereka sesudah itu, sungguh-sungguh melampaui batas dalam berbuat kerusakan di muka bumi ini.

Kedua ayat di atas sangat jelas mengecam dan memberi hukuman yang sangat keras terhadap pelaku tindakan kriminal dan membunuh manusia-manusia yang tidak berdosa. Al-Quran menekankan etika antar komunal sebagai satu proses mengendalikan kerusakan yang disebabkan oleh fitnah. Perburuan kaum Mekkah kepada kaum muslim dan juga pengusiran kaum tak berdosa dari rumah mereka, semakin berat pula hukuman yang dijatuhkan demi menunaikan keadilan punitif. Maka penggunaan kekerasan, sebagaimana yang dinyatakan al-Quran, bersifat defensif dan terbatas pada pelanggaran dalam hubungan manusia. ${ }^{24}$ Al-Quran

${ }^{24}$ Ibid., h. 200. 
membenarkan penggunaan kekerasan untuk menegakkan suatu tatanan yang melindungi kesejahteraan dasar umat Islam melawan musuh dari dalam dan dari luar.

Apabila terorisme dilihat dari konteks syari'at, kata jihad dijadikan sebagai ideologi dari pada terorisme kita perlu kaji ulang pengertian teroris dari sudut pandang syari'at. Secara etimologi yaitu tindakan teror disebut dengan kata irhab, orangnya disebut irhabiy (teroris). Sedangkan pahamnya itu disebut terorisme atau (irhabiyah). ${ }^{25}$ Dengan demikian perlu kita pertanyakan lagi apakah teroris itu tergolong pidana? Nah kalau kita merujuk terhadap konteks pidana, maka dalam Syariat Islam itu termasuk bagian kecil dari hudud hirabah, yaitu perbuatan yang menimbulkan kekacauan di masyarakat sehingga mengganggu ketentraman umum. ${ }^{26}$

Adalah kewajiban Muslimin untuk menegakkan kebajikan dan melawan kemungkaran, banyak cara untuk melakukan kewajiban ini. Tetapi jelas menurut ajaran Islam bahwa penggunaan kekerasan apalagi teror merupakan tindakan kriminal. Bahkan tindakan-tindakan kekerasan dalam menegakkan kebajikan dan menumpas kemungkaran merupakan satu bentuk ketidakadilan dan kezaliman (zhulm). ${ }^{27}$

Jadi, perlu adanya satu langkah prespektif untuk mencegah meluasnya efek jelek yang ada dan untuk membenahi akibat yang diderita kaum lemah karena kesalahan para pendosa yang tak bermoral serta tak bertuhan. Dengan kata lain, "perjuangan" dan "upaya" religius (makna kunci kata jihad) melalui kekerasan adalah kampanye ilahi yang mengambil posisi berseberangan dengan ketidakpercayaan. Bukanlah semua kaum kafir (yang tidak percaya) yang menjadi sasaran kekerasan, melainkan kaum kafir yang menunjukkan permusuhan terhadap Islam melalui fitnahlah yang menjadi targetnya

${ }^{25}$ Fauzan Al-Anshari “ Terorisme Dalam Persepektif Barat dan Islam” dalam Abdul Zulfidar Akaha (Editor), Terorisme Konspirasi Anti Islam, Jakarta: Pustaka al-Kausar, 2000, h. 166.

${ }^{26}$ Ibid, h. 167.

${ }^{27}$ Azyumardi Azra, Konflik Baru..., h. 81. 
Terorisme dengan teorinya adalah teror, itu adalah kejahatan atas kemanusiaan. Sementara agama adalah agama, pengertian tersebut harus betul-betul dipahami terlebih dahulu guna mencegah akses negatif, menurut Nurcholish Madjid, Islam sejatinya adalah agama yang berwatak (hanafiah alsamhah), yakni yang bersemangat mencari kebenaran, yang lapang toleran, tanpa kekufuran, dan tidak terbelenggu jiwa. Kata al-Islam itu sendiri pada mulanya bukan sebuah agama, tetapi sikap pasrah, damai, kasih sayang, keselamatan, karena itu Islam di dalam al-Qur'an, disebut menjadi agama kaffatan al-linnas untuk semua umat manusia. ${ }^{28}$

Terorisme sebagai kekerasan politik sepenuhnya bertentangan dengan etos kemanusiaan Islam. Islam mengajarkan etos kemanusiaan yang sangat menekankan kemanusiaan universal. Islam menganjurkan umatnya untuk berjuang mewujudkan perdamaian, keadilan, dan kehormatan. Tetapi perjuangan itu haruslah tidak dilakukan dengan cara-cara kekerasan atau terorisme. Setiap perjuangan untuk keadilan harus dimulai dengan premis, bahwa keadilan adalah konsep universal yang harus diperjuangkan dan dibela setiap manusia.

Islam menganjurkan dan memberikan justifikasi kepada Muslim untuk berjuang, berperang (harb) dan menggunakan kekerasan (qital) terhadap para penindas, musuh-musuh Islam dan pihak luar yang menunjukkan sikap bermusuhan dan tidak mau hidup berdamai dengan Islam dan kaum Muslimin. ${ }^{29} \mathrm{Jadi}$, setiap jihad yang mengarah kepada penghancuran tanpa makna kehidupan manusia dan mengabaikan keprihatinan-keprihatinan mengenai perdamaian berkeadilan, maka ia adalah jihad non Quranik. ${ }^{30}$

Dalam semua perspektif itu, harus diakui, terdapat individu dan kelompok-kelompok Muslim yang melakukan kekerasan politik, yang mengandung sejumlah elemen justifikasi moral. Tindakan kekerasan politik (terorisme)

28 Perta, Jurnal Komunikasi Perguruan Tinggi Islam, Vol. V/No.2/2002, h. 4.

${ }^{29}$ Azyumardi Azra, Konflik Baru..., h. 80-81.

${ }^{30}$ Abdul Aziz Sachedina, Kesetaraan Kaum...., h. 210. 
yang dilakukan para pejuang dan kelompok-kelompok Palestina melawan terorisme (state terorism) yang dilakukan negara Zionis Israel, misalnya; memiliki justifikasi moral dari ketertindasan yang mereka derita dalam waktu yang panjang. Bangsa Palestina telah dirampas hak-haknya oleh Israel yang didukung hampir tanpa reserve oleh Amerika Serikat dan banyak negara Barat lain untuk mendapatkan perdamaian dan keadilan. ${ }^{31}$

Meski ada unsur justifikasi moral dalam perjuangan yang dilakukan kelompok Muslim, seperti PLO. Para pejuang Palestina seharusnya tetap mengupayakan pencarian dan pengembangan cara-cara lain (damai) untuk melawan penindasan dan ketidakadilan. Hal ini penting, karena perjuangan melawan penindasan yang dilakukan kelompok-kelompok Muslim itu telah terlanjur distigmatisasikan sebagai "Muslim terrorism" atau bahkan "Islamic terrorism" yang pada gilirannya merusak dan menghancurkan citra Islam sebagai agama damai dan perdamaian (Islam; salam). Apalagi di Palestina sendiri terdapat dua kubu yang berbeda ediologi antara faksi Fatah dan Hamas yang sulit untuk disatukan sehingga posisi tawar di dunia Internasional semakin lemah.

\section{Kesimpulan}

Dari uraian diatas dapat diambil beberapa kesimpulan di antaranya:

1. Jihad artinya adalah kesungguhan, kekuatan, dan kelapangan jadi dalam hal ini jihad bukan hanya melawan musuh tetapi bila ada seorang pemimpin yang memerangi pengangguran, kemiskinan, memberantas maksiat demi mencapai ridha Allah dan demi kesejahteraan rakyatnya maka hal ini bisa juga disebut dengan jihad.

2. Jihad bukan hanya dengan jiwa atau perang militer akan tetapi bisa juga jihad dapat dimaknai dalam bentuk lain seperti mengorbankan harta, pengajaran dan pendidikan juga dapat lewat siyasah

${ }^{31}$ Azyumardi Azra, Konflik Baru..., h. 82. 
3. Istilah terorisme sudah muncul pada abad 18, namun istilah tersebut mulai populer pasca tragedi 11 September, peristiwa yang cukup bersejarah tersebut muncul akibat ketidakadilan negara adi daya tersebut terhadap dunia ketiga, dan menerapkan kebijaksanaan stereo ganda terhadap Palestina dan Israel, maka apabila AS ingin aman dari terorisme maka kebijakan dalam dan luar negerinya harus diubah.

4. Terorisme yang dilekatkan kepada Islam hanyalah perang media massa maupun elektronik Barat. Karena terorisme sebelum terjadinya pertiwa WTC telah banyak terjadi. Justru penyerangan Israel kepada Palestina dan Libanon, dan penyerangan Amerika atas Afghanistan dan Irak lebih biadab daripada teroris yang mereka kejar-kejar selama ini cari.

5. Ada dua kategori terorisme. Pertama, adalah horrific terrorism, yakni terorisme yang benar-benar jahat karena menghancurkan kekayaan pribadi dan negara serta membunuh jiwa tanpa alasan yang rasional dan dengan cara yang tidak konvensional. Kedua, heroic terrorism, yakni tindakan terorisme untuk memperjuangkan hidup, seperti bom bunuh diri yang dilakukan pemuda Palestina. Tindakan yang dilakukan karena tidak mempunyai pilihan lain.

6. Dalam pandangan hukum Islam, aksi terorisme jelas dikategorikan sebagai perbuatan yang haram karena bertentangan dengan tujuan syariat yaitu untuk kemaslahatan kehidupan manusia di dunia. Sebaliknya Islam adalah agama yang cinta perdamaian, rahmat li allamin. 


\section{DAFTAR PUSTAKA}

Ahmad Musthafa al-Maraghi, Tafsir al-Maraghi, Cairo: Dar alFikr, t.th. Jilid IV.

Abu Abdillah Muhammad Ismail al-Bukhari, Shahih Bukhari,

Beirut: Dar al-Shaab, t.th. Juz II

Anders Uhlin, Oposisi Berserak, Bandung: Mizan,1998.

Abdul Aziz Sachedina, Kesetaraan Kaum Briman, Jakarta:

Serambi Ilmu Semesta, 2001

Azyumardi Azra, Konflik Baru Antar Peradaban, Jakarta:

Grafindo Persada, 2002, Cet. I.

Departemen Pendidikan dan Kebudayaan, Kamus besar Bahasa

Indonesia, Jakarta: Balai Pustaka, 1999.

Eko Prasetyo, Membela Agama Tuhan, Yogyakarta: Pustaka Pelajar, 2003.

Hamka, Tafsir al-Azhar, Jakarta: Pustaka Panjimas, t.th. Juz X.

Juhaya S. Praja, Islam Globalisasi \& Kontra Terorisme,

Bandung: Kaki Langit Membangun Peradaban dengan Ilmu, 2004, Cet. I.

Jurnal BASIS, Jurnalisme Seribu Mata, No. 11-12, Tahun ke-53, Yogyakarta, 2004.

Mark Juergensmeyer, Teror Atas Nama Tuhan, Jakarta:

Nizam Press: 2002, Cet. I.

M.Quraish Shihab, Tafsir al-Misbah, Jakarta: Lentera Hati, 2002.

Fauzan Al-Anshari “ Terorisme Dalam Persepektif Barat dan Islam" dalam Abdul Zulfidar Akaha (Editor), Terorisme Konspirasi Anti Islam, Jakarta: Pustaka alKausar, 2000

Perta, Jurnal Komunikasi Perguruan Tinggi Islam, Vol.

V/No.2/2002.

Sady Abu Jaib, al-Qamus al-Fiqhi Lughatan wa Istilahan,

Damaskus: Dar al-Fikr, 1998.

Sayid Qutub, Fi Zhilal al-Quran, Beirut: Dar al-Arabiyah, t.th.

Wahbah al-Zuhaily, al-Fiqh al-Islam wa Adillatuhu, Beirut:

Dar al-Fikr, 1997, Cet. IV. Jilid VIII. 